\title{
PENERAPAN SISTEM PENCATATAN DAN METODE PENILAIAN PERSEDIAAN (Pada UKM Deden Batik dan Nanda Batik Tasikmalaya)
}

\author{
R. Ait Novatiani \\ aitnovatiani@gmail.com \\ R. Adjeng Mariana F
}

Sri Lestari

\section{UNIVERSITAS WIDYATAMA}

\begin{abstract}
ABSTRAK
Tujuan dari kegiatan program ipteks bagi masyarakat (IbM) ini adalah untuk mengembangkan dua mitra, yaitu Deden Batik dan Nanda Batik kearah UKM yang lebih mandiri secara ekonomi dan memiliki keunggulan bersaing di kancah MEA. Dalam mewujudkan ke arah yang lebih mandiri secara ekonomi dan memiliki keunggulan bersaing, maka tim memberikan materi dan pelatihan dalam pengelolaan persediaan, yaitu dengan memberikan materi dan pelatihan mengenai sistem pencatatan dan metode penilaian persediaan. Hasil dari pengabdian pada masyarakat yang telah dilaksanakan pada kedua mitra (Deden Batik dan Nanda Batik) di Tasikmalaya, maka kedua mitra (Deden batik dan Nanda batik) mampu membuat sitem pencatatan persediaan dan metode penilaian persediaan dengan menggunakan Microsoft Excel sehingga kedua mitra dapat dapat mengetahui persediaan yang ada di gudang baik persediaan yang dibeli (persediaan yang masuk ke gudang), persediaan yang dijual (persediaan yang keluar dari gudang) dan saldo (sisa) persediaan yamg ada di gudang, yang akan memudahkan dalam peengelolaan persediaannya dan membantu kedua mitra dalam proses produksi, pesanan barang dan penjualan barang. Berdasarkan hasil pengabdian pada masyarakat, maka dapat disimpulkan bahwa kedua mitra UKM (Deden Batik dan Nanda Batik) mampu membuat sistem pencatatan persediaan dan metode penilaian persediaan dengan menggunakan Microsoft Excel.
\end{abstract}

Kata Kunci : Sistem Pencatatan Persediaan, Metode Penialian Persediaan, UKM

\section{PENDAHULUAN}

Perkembangan usaha kecil dan menengah (UKM) disegala sektor usaha cenderung tidak stabil. Ketidakstabilan yang terjadi pada usaha kecil menengah (UKM) disebabkan diantaranya adalah kurangnya modal dan kurangnya karyawan yang kompeten di bidangnya khususnya dalam pengeloaan persediaan.

Persediaan merupakan unsur yang paling penting di dalam kegiatan sebuah perusahaan baik perusahaan besar maupun untuk perusahaan kecil. Persediaan menandakan adanya barang-barang yang tujuannya untuk dijual kembali melalui kegiatan perusahaan yang normal serta barang yang masih dalam proses produksi. Menurut Warren (2005) pengertian persediaan adalah:

"Persediaan merupakan 1). Barang dagang yang disimpan kemudian dijual dalam kegiatan bisnis perusahaan, 2). Barang dalam proses yang digunakan dalam proses produksi kemudian dijual dalam kegiatan bisnis perusahaan." Agar pengeloaan persediaan baik maka sistem pencatatan dan metode penilaian 
persediaan harus dilakukan oleh setiap usaha kecil dan menengah (UKM).

Sistem pencatatan dalam perusahaan ada 2 macam yaitu sistem pencatatan persediaan periodik dan sistem pencatatan perpetual.MenurutWarren (2005) sistem pencatatan persediaan adalah:

"Sistem pencatatan persediaan ada 2 macam yaitu: 1). sistem pencatatan periodik dan 2). Sistem pencatatan perpetual."

Metode penilaian persediaan ada 3 macam yaitu metode penilaian persediaan berdasarkan metode FIFO, LIFO danAverage. Penilaian persediaan memegang peranan penting dalam proses mempertahankan pendapatan dan biaya untuk satu periode tertentu.

Menurut Warren (2008) metode penilaian persediaan adalah:

"Metode penilaian persediaan berdasarkan harga perolehan (at cost) ada 3 macam yaitu: 1). metode FIFO, 2). Metode LIFO dan 3). Metode average."

Sitem pencatatan dan metode penilaian persediaan sebaiknya dilakukan oleh para usaha kecil menengah (UKM) dalam pengelolaan persediaannya. Agar dapat diketahui berapa barang yang masuk atau keluar gudang, serta dapat segera mengetahui berapa persediaan barang di gudang, sehingga memudahkan perusahaan dalam pengelolaan persediaan bahan baku, membantu proses produksi dan pesanan barang (Baridwan, 2004)

Begitu juga yang terjadi pada usaha kecil dan menengah (UKM) Deden Batik dan Nanda Batik, dimana kedua UKM tersebut merupakan mitradari kegiatan program ipteks bagi masyarakat (IbM). Kedua Mitra baik Deden Batik maupun Nanda Batik dalam pengelolaan persediaannya belum melakukan sistem pencatatan persediaan dengan baik dan benar serta belum melakukan dan belum menggunakan metode penilaian persediaan. Dengan demikian baik Deden Batik maupun Nanda Batik tidak dapat mengetahui berapa barang yang masuk atau keluar gudang, serta tidak dapat segera mengetahui berapa persediaan barang di gudang, akibatnya akan menghambat dalam proses produksi dan pesanan barang.

Deden batikmemiliki pabrik yang memproduksi batik cap/kombinasi dan tulis, serta 2 (dua) buah toko/gerai batik di lokasi strategis di Jalan Cigeureung dan Jalan Indihiang - Tasikmalaya yang dilengkapi sarana listrik, telepon dan internet. Gerai yang terletak di Jalan Cigeureng terletak di jalan utama tetapi belum memiliki daya tarik yang menyolok sehingga pelanggan kadang kesulitan membedakan gerai yang dimiliki oleh Deden Batik dengan gerai di sebelahnya, yaitu Batik Rizqi yang memiliki lahan gerai lebih luas ke samping dan terbuka dengan memajang beragam lembaran batik dan batik yang sudah jadi, sehingga kelihatannya pesaingnya lebih memiliki daya tarik yang kompleks.

Nanda Batik merupakan pelopor batik yang berjasa mengangkat keterpurukan Batik Tasik dari kepunahan. Dimulai dari ketertarikan untuk menggeluti usaha batik di tahun 2000 pendirinya Ade Suryana SE. MM memilih untuk hijrah kembali ke Kota Tasikmalaya membuka usaha di bidang batik. Walaupun secara turun temurun orang tuanya yang telah terlebih dulu menggeluti usaha batik, tetapi Ade Suryana belum tertarik untuk meneruskan usaha orang tuanya. Perlahan tapi pasti didirikannya Nanda Batik sebagai cikal bakal usahanya sampai sekarang.

Berdasarkan uraian di atas menunjukkan bahwa pentingnya penerapan sistem pencatatan persediaan dan metode penilaian persediaan pada kedua UKM tersebut (Deden batik dan Nanda batik), sehinggamemudahkan dalam pengelolaan persediaannya.

\section{METODOLOGI PELAKSANAAN}

Metode Pelaksanaan yang dilakukan dalam kegiatan program ipteks bagi masyarakat (IbM) ini (pengabdian pada 
masyarakat) adalah pelatihan. Dalam pelatihan terhadap kedua mitra UKM baik kepada Deden Batik dan Nanda Batik dilakukan sebagai berikut:

\subsection{Metode Pelaksanaan}

1. Melakukan survei pendahuluan dan sosialisasi, perencanaan dan penetapan program kepada kedua mitra (Deden Batik dan Nanda Batik) serta mendiskusikan materi dan pelatihan yang akandilatihkan. Disini tim melakukan pretest akan kemampuan kedua mitra tersebut.

2. Membuat materi pelatihan sistem pencatatan persediaan dan metode penilaian persediaan.

3. Memberikan pelatihan sistem pencatatan persediaan dan metode penilaian persediaan menggunakan Microsoft Excel.

4. Melakukan pendampingan.

5. Melakukan evaluasi.

\subsection{Metode Pendekatan}

Adapun metode pendekatan yang ditawarkan untuk menyelesaikan persoalan mitra program yang telah disepakati bersama dalam kurun waktu 8 (delapan) bulan untuk merealisasikan pengabdian pada masyarakat adalah penjajakan pengetahuan peserta dengan pre-test dan post-test, penyadaran dengan cara pemberian materi ceramah dialogis, memberikan pelatihan di bidang akuntansi khususnya sistem pencatatan persediaan dan metode penilaian persediaan.

\subsection{Partisipasi Mitra}

UKM menyambut dengan antusias dan bersedia untuk bekerjasama dengan tim pengabdian pada masyarakat Universitas Widyatama Bandung, berpartisipasi mengikuti pelatihan, pendampingan dan evaluasi yang diberikan tim pengabdian

\subsection{Evaluasi Pelaksanaan Program}

Evaluasi pelaksanaan program dilakukan dengan mengamati dan meninjau bagaimana sistem pencatatan persediaan dan metode penilaian persediaan menggunakan Microsoft Excel diterapkan dalam kegiatan usahanya khusunya dalam pengeloaan persediaannya.

\section{HASIL DANLUARAN}

\subsection{HASIL}

Hasil dari pengabdian pada masyarakat dalam kegiatan program Ipteks bagi Masyarakat (IbM) yang sudah dilakukan oleh tim di kedua mitra, yaitu Deden Batik dan Nanda Batik di Tasikmalaya adalah sebagai berikut:

1. Tim melakukan sosialisasi pelaksanaan IbM kepada kedua mitra pada hari Minggu, tanggal 23 April 2017, yaitu membahas mengenai :
A. Maksud dan tujuan dilakukan pengabdian pada masyarakat (P2M).

B. Permasalahan-permasalahan yang dihadapi oleh kedua mitra

C. Kegiatan / pelatihan-pelatihan yang akandilaksananakan pada kedua mitra.

2. Tim melaksanakan pelatihan kepada kedua mitra, yaitu :

Pelatihan yang dilaksanakan pada hari Kamis, tanggal 18 Mei 2017 meliputi:

1. Tim memberikan materi dan pelatihan mengenai sistem pencatatan dan metode penilaian persediaan dengan menggunakan Microsoft Excel kepada karyawan di kedua mitra UKM (Deden Batik dan Nanda Batik).Adapun materi dan pelatihan sistem pencatatan persediaan yang diberikan kepada kedua mitra UKM (Deden Batik dan Nanda Batik) adalah sistem pencatatan persediaan perpetual. Pada sistem pencatatan persediaan perpetual, yaitu: 
a). Jika terjadi pembelian, maka barang dagang tersedut dicatat ke rekening persediaan, dimana dicatat sebagai berikut:

Dr Persediaan

Cr Kas / Utang

b). Jika terjadi penjualan, maka barang dagang tersedut dicatat ke rekening persediaan dan dicatat ke rekening harga pokok penjualannya, dimana dicatat sebagai berikut:

Dr Kas / Piutang
Cr Penjualan

Dr Harga Pokok Penjualan

$\mathrm{Cr}$ Persediaan

Adapun materi dan pelatihan metode penilaian persediaan yang diberikan kepada kedua mitra UKM (Deden Batik dan Nanda Batik) adalah metode penilaian persediaan berdasarkan metode average dengan sistem pencatatan persediaan perpetual. Pada metode penilaian persediaan dengan perpetual, yaitu:

Metode : MOVING AVERAGE

Halaman : 1

\begin{tabular}{|r|r|r|r|r|r|r|r|r|r|r|}
\hline \multicolumn{2}{|c|}{ Tgl. } & \multicolumn{3}{c|}{ Pembelian } & \multicolumn{3}{c|}{ HPP } & \multicolumn{3}{c|}{ saldo } \\
\hline \multicolumn{2}{|c|}{} & Q & P & T & Q & P & T & Q & P & T \\
\hline Jan & 1 & & & & & & & 50 & 120 & 6,000 \\
\hline & 3 & 200 & 125 & 25,000 & & & & 250 & 124 & 31,000 \\
\hline & & & & 150 & 124 & 18,600 & 100 & 124 & 12,400 \\
\hline & 11 & 300 & 135 & 40,500 & & & & 400 & 132 & 52,900 \\
\hline & 15 & 200 & 140 & 28,000 & & & & 600 & 135 & 80,900 \\
\hline & 19 & & & & 325 & 135 & 43,875 & 275 & 135 & 37,125 \\
\hline & 23 & & & & 100 & 135 & 13,500 & 175 & 135 & 23,625 \\
\hline & & & & & & & & & & \\
\hline \multicolumn{2}{|l|}{ Jumlah } & $\mathbf{7 0 0}$ & & $\mathbf{9 3 , 5 0 0}$ & $\mathbf{5 7 5}$ & & $\mathbf{7 5 , 9 7 5}$ & $\mathbf{1 7 5}$ & & $\mathbf{2 3 , 6 2 5}$ \\
\hline
\end{tabular}

Mengggunakan metode penilaian persediaan dengan sistem pencatatan perpetual, maka akan diketahui setiap saat mengenai persediaan yang dibeli (persediaan yang masuk ke gudang), persediaan yang dijual (persediaan yang keluar dari gudang) dan saldo (sisa) persediaan yamg ada di gudang.

\subsection{LUARAN}

Berdasarkan materi yang sudah diberikan dan pelaksanaan pelatihan oleh tim kepada karyawan di kedua mitara UKM (Deden Batik dan Nanda Batik) di Tasikmalaya, maka dapat dijelskan sebagai berikut:

Setelah melakukan sosialisasi pelaksanaan IbM kepada kedua mitra UKM, maka : a. Maksud dan tujuan dari pengabdian pada masyarakat (P2M) sudah tercapai.

b. Permasalahan-permasalahan yang dihadapi oleh kedua mitra sudah terpecahkan dan sudah ada solusinya, yaitu kedua mitra sudah diberikan materi dan pelatihan sesuai dengan permasalahan yang dihadapi yaitu materi sistem pencatatan persediaan dan metode penilaian persediaan dengan menggunakan Microsoft Excel.

c. Kegiatan pengabdian pada masyarakat (P2M) sudah dilaksananakan pada kedua mitra sesuai dengan jadual yang sudah disepakati. 
Setelah timmemberikan materi dan melaksanakan pelatihan kepada kedua mitra UKM (Deden Batik dan Nanda Batik mengenai sistem pencatatan persediaan dan metode penilaian persediaan dengan menggunakan Microsoft Excel, maka:

karyawan di kedua mitra UKM (Deden batik dan Nanda batik) mampu membuat sistem pencatatan persediaan dan metode penilaian persediaan sehingga kedua mitra UKM baik Deden batik maupun Nanda batik dapat mengetahui persediaan yang ada di gudang baik persediaan yang dibeli (persediaan yang masuk ke gudang), persediaan yang dijual (persediaan yang keluar dari gudang) dan saldo (sisa) persediaan yamg ada digudang, sehingga memudahkan dalam peengelolaan persediaannya. Hal ini sejalan dengan teori yang dikemukakan oleh Baridwan (2004), yaitu adanya sistem pencatatan persediaan akan memudahkan perusahaan dalam pengelolaan persediaan barang, membantu proses produksi dan pesanan barang serta penjualan barang.

\section{KESIMPULAN}

Berdasarkan hasil dari pengabdian pada masyarakat yang telah dilaksanakan pada kedua mitra UKM (Deden Batik dan Nanda Batik) di Tasikmalaya adalah:
Kedua mitra UKM (Deden Batik dan Nanda Batik) mampu membuat sistem pencatatan persediaan dan metode penilaian persediaan dengan menggunakan Microsoft Excel. Sehingga kedua mitra UKM dapat mengetahui persediaan yang ada di gudang baik persediaan yang dibeli (persediaan yang masuk ke gudang), persediaan yang dijual (persediaan yang keluar dari gudang) dan saldo (sisa) persediaan yang ada digudang, sehingga memudahkan dalam peengelolaan persediaannya dan membantu kedua mitra dalam proses produksi, pesanan barang dan penjualan barang.

\section{DAFTAR PUSTAKA}

Ikatan Akuntan Indonesia. 2010. Standar Akuntansi Keuangan- ETAP: Jakarta. Salemba Empat.

Warren, C. S., Reeve, J. M., dan Fees, P. E. (2008). Pengantar Akuntansi. Jakarta: Salemba Empat.

Zaki, B. (2004). Intemediate Accounting. Yogyakarta: BPFE. 